\title{
CORRECTION
}

\section{Correction to: PDCAT: a framework for fast, robust, and occlusion resilient fiducial marker tracking}

\author{
Oualid Araar ${ }^{1} \cdot$ Imad Eddine Mokhtari $^{1} \cdot$ Mohamed Bengherabi $^{1}$
}

Published online: 18 September 2020

(c) Springer-Verlag GmbH Germany, part of Springer Nature 2020

\section{Correction to: Journal of Real-Time Image Processing https://doi.org/10.1007/s11554-020-01010-w}

In the original publication of the article, the family name of the 1 st author has been changed to Araar.

The Original article has been corrected.

Publisher's Note Springer Nature remains neutral with regard to jurisdictional claims in published maps and institutional affiliations.

The original article can be found online at https://doi.org/10.1007/ s11554-020-01010-w.

Oualid Araar

oualid.araar@emp.mdn.dz; oualid.araar@gmail.com

1 Ecole Militaire Polytechnique, Bordj el Bahri, B.P 17, Algiers, Algeria 